
\title{
25 Research Soure \\ Using Behaviour Change Theories to Understand Pediatric Emergency Discharge Communication Interventions
}

\section{Allyson J Gallant}

Dalhousie University School of Nursing

\section{Andrea Bishop}

Dalhousie University School of Nursing

\section{Christine Cassidy}

Dalhousie University School of Nursing

\section{Jeanne Egar}

Dalhousie University School of Nursing

Janet Curran ( $\boldsymbol{\sigma}$ jacurran@dal.ca )

Dalhousie University https://orcid.org/0000-0001-9977-0467

\section{Research}

Keywords: Pediatric emergency care, discharge communication, interventions, behaviour change techniques, reporting guidelines

Posted Date: April 20th, 2020

DOl: https://doi.org/10.21203/rs.3.rs-21813/v1

License: (c) (1) This work is licensed under a Creative Commons Attribution 4.0 International License. Read Full License 


\section{Abstract \\ Background}

Interventions to improve discharge communication in emergency practice settings are inherently complex and incorporate multiple strategies aimed at patient, caregiver and healthcare provider behaviours.

Behaviour change theories, including the capability-opportunity-motivation-behaviour (COM-B) model and Behaviour Change Technique Taxonomy version 1 (BCTTv1), provide consistent language for identifying and evaluating the active components of interventions. The objectives of this study were to: (1) identify common barriers and enablers to discharge communication interventions and (2) describe behaviour change techniques (BCTs) present in pediatric emergency discharge communication interventions aimed at patients, caregivers and health care providers.

\section{Methods}

We conducted a secondary analysis of 35 experimental and quasi-experimental studies included in a narrative synthesis of discharge communication interventions in pediatric emergency care. Included studies were reviewed to identify reported barriers and enablers to implementation and intervention effectiveness, which were then mapped to the COM-B model. Trained BCT coders independently coded intervention descriptions using the BCTTV1 as a coding framework. Consensus was used to resolve any discrepancies. BCTs were analyzed using descriptive statistics to determine the frequency of the 93 individual BCTs and 16 BCT categories for patient/caregiver and health care provider interventions.

\section{Results}

Barriers and enablers were identified at the patient/caregiver, health care provider, intervention and health system levels. Psychological capability was the most frequently coded COM-B component. Of the 33 studies that included BCTs, 29 interventions targeted patients or caregivers. A total of 20 different individual BCTs were identified across the interventions in the 33 studies. The number of BCTs identified in each study ranged from 1-9 BCTs, with most $(n=14,42 \%)$ interventions containing one BCT. Reporting deficiencies were noted related to adequate details of intervention components and implementation fidelity.

\section{Conclusions}

The COM-B model and BCTTV1 proved to be useful tools to provide a foundational understanding of the common mechanisms used in pediatric discharge communication interventions. With only a fraction of the available BCTs were used in the included studies, future research is needed to explore the utility of 
other BCTs to address common implementation barriers and improve the effectiveness of discharge communication interventions.

\section{Contributions To The Literature}

- Discharge communication interventions in pediatric emergency care require strategies aimed at health care provider, caregiver and patient behaviours. While a number of barriers were identified at the health care provider and intervention level, the majority of BCTs in this review targeted caregivers.

- Instructions on how to perform the behaviour was the most common BCT targeting parents. Techniques targeting healthcare providers' discharge communication behaviours were rare.

- Behaviour change theories can assist with identifying active components of pediatric discharge communication interventions. Our findings contribute to the limited body of knowledge regarding theory-based interventions in pediatric emergency care.

\section{Background}

Interventions in health care are often complex and involve a number of components, targets, behaviours, and outcomes [1]. Understanding the components that comprise a successful intervention can provide important information for the development of future interventions and can result in more efficient use of health care resources [2]. A number of intervention classification frameworks have been developed over recent years, including the Effective Practice and Organization of Care (EPOC) classification system [3] and the Template for Intervention Description and Replication (TIDiER) [4], that aim to standardize intervention descriptions [5]. While these classification systems allow for improved comprehensiveness of intervention reporting, there is also evidence to suggest that using systematic, theoretically-derived classification systems improve the replicability of health behaviour interventions $[1,6]$.

The capability-opportunity-motivation-behaviour (COM-B) model is a behaviour change framework which suggests that behaviours are the result of interactions within capabilities, opportunities and motivations [7]. The COM-B model is further differentiated into six components; physical capability, psychological capability, physical opportunity, social opportunity, reflective motivation, and automatic motivation [7] and has been used to understand barriers and enablers across a range of health contexts $[8,9]$.

Combining both intervention classification and health behaviour theory, the Behaviour Change Technique Taxonomy version 1 (BCTTV1) provides consistent language for identifying and evaluating the active components of interventions [10]. A behaviour change technique (BCT) is defined as an "observable, replicable and irreducible component of an intervention designed to alter or redirect causal processes that regulate behaviour" [10]. As such, they are often referred to as the 'active ingredients' of an intervention's design. The BCTTV1 includes 93 individual techniques with labels and definitions organized into 16 BCT categories [10]. The BCTTV1 has been used to evaluate and design a number of health care interventions in varying clinical settings, including medication adherence [11], weight management [12], physical activity $[13,14]$, antimicrobial resistance [15], and diabetes care $[16,17]$. Previous research has found the 
BCTTv1 to be a useful tool for classifying intervention components and standardizing intervention language [15-18].

Pediatric emergency department (ED) settings can be noisy and chaotic and the discharge process can be a stressful for patients and families. Interventions to improve discharge communication are often complex and can incorporate multiple strategies aimed at health care provider, caregiver and patient behaviours $[19,20]$. Effective discharge communication interventions include standardizing content delivered through both verbal and written modes, and ensuring patient comprehension and recall through strategies such as demonstration of the behaviour, prompts, and social support [21, 22]. Findings from a recent systematic review and narrative synthesis of pediatric discharge communication found that the majority of interventions across both acute and chronic illness presentations were aimed at improving caregiver comprehension of health information [23]. Further, many of these discharge communication interventions include multiple intervention components (e.g., education, reminders) and targets (e.g., patient and family, health care provider and system), making it difficult to discern which intervention components, or interaction of multiple components, resulted in the measured outcome $[2,23,24]$.

To date, behaviour change frameworks have yet to be used to identify the barriers, enablers and active ingredients in emergency discharge communication interventions. Using the results from a recent systematic review and narrative synthesis of pediatric emergency discharge communication, the objectives of this study were to: (1) map identified intervention barriers and enablers identified by authors in the experimental and quasi-experimental studies to the COM-B model, and (2) describe common BCTs included ED discharge communication interventions.

\section{Methods}

We conducted a secondary analysis of 35 experimental and quasi-experimental studies included in a systematic review and narrative synthesis of discharge communication in pediatric emergency care to gain a better understanding of the behaviours related to discharge communication and the characteristics of existing interventions [23]. A full description of the narrative synthesis protocol [25] and findings [23] can be found elsewhere. Coders were blinded to the intervention function classification completed during the narrative synthesis.

\section{Identifying and mapping intervention barriers and enablers}

All included studies were analyzed by two reviewers (JAC and AJG). First, the full text articles were imported into NVivo 11 qualitative software [27], and the study reports were reviewed to identify barriers and enablers to intervention implementation and effectiveness as reported by the study authors. The reviewers met after coding every 5-7 studies to compare consistency and discuss any discrepancies. Once barriers and enablers were identified they were mapped onto relevant domains within the COM-B model. The two reviewers independently mapped the barriers and enablers to the components of the 
COM-B model and then met to compare findings of the mapping exercise. Discrepancies in mapping were resolved through discussion.

\section{BCTTV1 coding}

Similar to other research [16], we developed rules a priori to guide BCT coding and reviewer consensus. The first rule was to code only those intervention components with sufficient detail to clearly identify a BCT. This prevented over-coding of interventions by limiting coder assumptions that a BCT could be present but poorly described. The second rule was specific to education interventions, which are common in discharge communication. We assumed that components of education intervention included at a minimum instruction on how to perform the behavior. Other BCTs were coded in education interventions only when sufficient details were provided.

Textual data from study reports were managed using NVivo 11[27]. All reviewers completed the online BCTTV1 training course [28] and received a copy of the 93 individual BCT definitions and examples from the BCTTV1 $[7,10]$ prior to coding. Four reviewers (AJG, AB, JE, CC) independently coded the intervention descriptions in all included studies. The study objectives were reviewed first to obtain a sense of the intervention target and outcomes of interest. The methods sections were then read in their entirety and analyzed to identify BCTs in the interventions. BCTs were only identified in content related to the intervention groups, as the control groups received either no intervention or standardized care.

Following independent coding, a consensus meeting has held to compare coding and resolve discrepancies. Coding discrepancies were discussed as a team and resolutions were achieved by consensus. When coding discrepancies could not be resolved, a fifth team member (JAC) was included in the discussion to help achieve consensus. We chose to reach consensus rather than use inter-coder reliability statistics as inter-coder agreement has not been well established in the literature [29]. All coding resolutions were then noted in the NVivo file. Descriptive statistics were used to determine the frequency of the 93 individual BCTs and 16 BCT categories for patient, caregiver and health care provider interventions. Our study report adheres to the Enhancing Transparency in Reporting the Synthesis of Qualitative Research (ENTREQ; [26]) checklist (see additional file 1).

\section{Results}

\section{Barriers and enablers}

Barriers and enablers were identified across patient/caregiver, health care provider, intervention and health system levels. All six domains of the COM-B model were identified across the barriers and enablers, with psychological capability being the most commonly identified domain across levels. The full list of barriers and enablers and identified COM-B domains are outlined in Table 1.

Patient/caregiver barriers ranged from low health literacy levels, feelings of anxiety and stress, and poor understanding of discharge instructions. Health care provider barriers included resistance to change and 
poor relationships with patients/caregivers. Complex interventions that required a substantial allotment of resources to implement was also identified as a key barrier. Finally, two important health system barriers included the chaotic nature of the ED context and limited access to primary care providers.

Enablers were also identified across studies. Enablers included providing caregivers with information early in the ED visit, having health care providers use pre-formatted discharge communication templates as part of the intervention, establishing links between the ED and primary care providers, and personalizing intervention content to the patient's needs.

\section{BCT Coding}

Two $[60,61]$ of the 35 experimental studies did not include identifiable BCTs as components of the interventions and were therefore not included in the analysis. These interventions either did not target behaviour change or did not provide enough detail in the methods sections to identify potential BCTs. Table 2 provides an overview of study characteristics and identified BCTs from the remaining 33 studies.

\section{Patient/Caregiver targeted interventions}

Of the 33 studies that included BCTs, 29 interventions targeted patients/caregivers. A total of 20 out of the 93 individual BCTs, from 12 of the 16 BCT categories, were identified in the interventions (Figure 1). The number of BCTs identified in each study ranged from 1-9 BCTs, with a mode of 1 BCT per intervention. The three most commonly coded BCTs in patient/caregiver interventions were:

4.1- Instruction on how to perform the behaviour. Fourteen studies included this component as part of their interventions [30-34, 37, 38, 42, 43, 47, 50, 53, 55, 62]. Interventions that included this BCT were most often aimed at asthma, fever, and gastroenteritis illness presentations.

e.g., "the video discusses methods for taking a temperature, outlines indications for contacting a physician, refutes common parental misconceptions about fever, and identifies methods to comfort a febrile child"[37].

5.1-Information about health consequences: Eleven interventions included information about health consequences [30, 33, 39, 47, 48, 50, 55-57, 63, 64]. This BCT was identified across numerous studies, including interventions aimed at pain management, mental health, and wound care.

e.g., "the instructions were legible, were written to be understood by a patient with a seventh-grade education, and included information concerning suture removal, wound care, signs of infection, and methods to reduce scarring"[30].

3.2- Social support (practical): Ten studies used practical social support in their interventions [33, 40, 43, $47,48,50,58,59,62,63]$. In one study [62], this BCT was used in two components of the intervention. Six of these interventions were aimed at asthma or mental health presentations $[43,47,50,58,62,63]$. 
e.g., "the educator also asked about and reinforced use of the asthma action plan, provided a referral for any identified obstacles, tried to help the family set goals to assure follow-up, and addressed any new concerns or questions as appropriate"[43].

Health care provider targeted interventions

Only eight of the 33 studies that included BCTs targeted health care provider behaviours. Four interventions solely targeted health care providers [35, 41, 44,51], while the other four interventions primarily targeted caregivers but also included health care providers $[42,48-50]$. Four of the potential 93 individual BCTs were identified from these eight interventions across four BCT categories: shaping knowledge, natural consequences, associations, and repetition and substitution (Figure 1). The four identified BCTs in health care provider interventions were:

4.1-Instruction on how to perform the behaviour. Four studies included this BCT as a component of their interventions [44, 49-51]. Two of the interventions were focused on asthma, one on mental health and one otitis media illness presentations. Further, one study [44] used this BCT at two different points in the intervention.

e.g., "...all nurses and Respiratory Care Practitioners (RCP) were instructed on the use of the plan to ensure that all healthcare providers delivered the same messages to the patients and parents" [51].

7.1- Prompts/Cues: This BCT was also identified in four interventions $[41,42,44,48]$. Two of these interventions targeted asthma, one targeted otitis media illness presentations, and the final intervention used prompts/cues to encourage families to purchase and use helmets.

e.g., "physicians were provided, during orientation sessions, with a small plasticized pocket cue card outlining a number of points to serve as the basis for counseling the family about the risks of cycling and the benefits of helmets"[48].

5.1-Information about health consequences: Two studies included this BCT $[35,50]$. One of the studies targeted asthma and the other targeted fever.

e.g., "each ED was introduced to the protocols through educational sessions outlining the importance of compliance with asthma care guidelines"[50].

8.1-Behaviour practice/rehearsal: Only one intervention included this BCT [49]. This intervention targeted mental health presentations and also included numerous intervention components targeted at caregivers and patients to increase use of outpatient mental health services and to decrease suicide attempts.

e.g., "clinicians with graduate mental health training received didactic training with role playing, observed intervention sessions, and were observed until a senior clinician certified them as proficient" [49].

\section{Discussion}


The application of the BCTTV1 was useful for identifying the active ingredients present in pediatric emergency discharge communication interventions targeting caregivers and health care providers. We identified 20 out of a possible 93 BCTs across all studies, indicating that less than a quarter of the available BCTs are commonly used in interventions to improve ED discharge communication. This low percentage of identified BCTs is consistent with other reviews of BCTs in diabetes care $[17,66]$ and medication adherence literature [67].

\section{Changing patient/caregiver behaviours}

The majority of ED discharge communication interventions from our analysis solely targeted caregivers. Instruction on how to perform the behaviour was the most commonly identified BCT in interventions across all illness presentations that aimed to improve caregiver compliance, comprehension, or recall of discharge instructions. This is not surprising as discharge communication is meant to instruct patients and caregivers on how to perform behaviours specific to managing care of their child at home. This finding is also consistent with BCTs identified in the diabetes [17, 66], cardiovascular disease [68], and physical activity [69] literature. Interestingly, many of the common BCTs used to address other health behaviours, including action planning [67], goal setting [66, 68, 70], self-monitoring of behaviours [67, 69-71], problem solving [70,72] and reducing negative emotions $[68,70]$ have not been widely used in discharge communication interventions to date. While education is a commonly employed behaviour change strategy, without the addition of BCTs like action planning and/or goal setting, it is unlikely to lead to changes in behavior [73, 74]. There is further evidence to suggest that interventions that incorporate barrier mitigation and problem solving along with action planning can be even more efficacious $[75,76]$. As such, there is an opportunity to leverage the strengths of these BCTs to examine their utility in conjunction with educational interventions for ED discharge communication.

We identified a subset of studies which incorporated practical social support as the only BCT [40,58], or combined with other BCTs $[33,43,47,48,50,59,62,63]$ to increase follow-up care after discharge from the ED to reduce inappropriate return visits. This is consistent with other studies which found that practical social support techniques such as phone call reminders and customized asthma care plans, can improve the likelihood of follow-up care with primary care providers [77]. Including social support in health-related interventions has been associated with long-term positive outcomes, especially in behaviour change studies [78, 79], as well as having an overall positive impact on health [80]. However, no significant impacts on system level outcomes, such as ED return rates or unscheduled care, have been found [77].

Finally, interventions targeting chronic illness presentations, like asthma and mental health, were more likely to include multiple BCTs compared to acute illness presentations. Of the 13 asthma interventions targeting patients/caregivers, five interventions included at least three BCTs [36, 42, 43, 50, 62]. Each of the three mental health interventions included between four and nine BCTs targeting patients/caregivers, significantly higher than the mode of one BCT per intervention in the majority of other studies $[47,49,63]$. 
As chronic disease often involves multiple interacting risk factors, management of these conditions may require more multi-component, complex interventions.

The identified barriers to effective ED discharge communication provides some guidance on which BCTs should be prioritized and evaluated moving forward [81]. BCTs associated with increasing familiarity and confidence in performing behaviours following ED discharge, such as demonstration of the behaviour and behavioural practice/rehearsal, may help to overcome barriers associated with improved teaching and demonstration. Future research should consider the possibility of a wider range of important patient and caregiver level barriers to effective discharge communication when designing intervention strategies

\section{Changing health care provider behaviours}

Few interventions in our analysis targeted ED health care provider behaviour. This is concerning given that effective discharge communication requires an interactive process between health care providers and patients/caregivers that includes assessment of comprehension [21]. By primarily focusing interventions on patients/caregivers, half of the discharge communication equation is missing.

Coding the barriers and enablers to intervention effectiveness allowed us to identify factors at the health care provider level that may affect uptake of the intervention. Some of the barriers identified at this level could be addressed by incorporating BCTs specifically targeting health care providers into the interventions. For example, health care providers' resistance to intervention uptake could be addressed by including habit forming, habit reversal, or restructuring the physical environment components in the intervention. These BCTs may help facilitate the uptake of new clinical behaviours. Additionally, health care providers' rapport with caregivers could be addressed by use of prompts/cues, which could support providing more consistent and comprehensive discharge communication. Other studies detailing health care provider-focused interventions have also identified prompts/cues and instruction on how to perform the behaviour as commonly coded BCTs [66]. Reminders have also been shown to be an effective strategy to change health care provider behaviours across health care settings [82], although factors such as patient preference may ultimately override their decision-making processes [83]. As only four studies in our analysis included BCTs targeting both caregivers and health care providers, greater evaluation of health care provider-focused behavioural interventions are needed.

\section{Intervention content descriptions}

While the majority of interventions in our analysis included education components, education content and delivery were rarely reported in enough detail to identify additional BCTs that might have been present. Our findings suggest there is a critical need for improvement in study reporting, particularly regarding details about intervention components and implementation strategies, clearly explicating assumptions about how the intervention is expected to work. This has been identified as an important factor to advance the science of behaviour change and improve replicability [84, 85]. Articles included in our analysis did not use a checklist, such as the TIDiER checklist, which has been widely available since 2014 [4]. Further, none of the included articles specified a taxonomy or classification system, like the 
BCTTV1, to describe individual intervention components. Use of a reporting guideline to guide intervention descriptions would greatly strengthen not only the findings generated from the evaluation of pediatric ED interventions, but also lead to greater ability to replicate studies and synthesize resulting evidence. Intervention fidelity not only assesses whether the intervention was delivered as planned, but provides important insight into how implementation varied and important barriers and facilitators to consider in future research [86].

\section{COM-B Intervention barriers and enablers}

To our knowledge, this is the first instance of using the COM-B model to describe barriers and enablers of discharge communication interventions. Applying this model to analyze barriers and enablers has been completed in other research areas, including a systematic review regarding testing for sexual transmitted infections [9]. Our analysis mapped intervention barriers and enablers to all six domains in the COM-B model, with most categorized under the psychological capability domain. Instruction on how to perform the behaviour and information about health consequences were two of the most commonly identified BCTs in patient, caregiver and health care provider interventions. While these frequently used BCTs may address some of the barriers in the psychological capabilities domain, clearly they provide insufficient coverage to address all existing barriers within this domain.

\section{Limitations}

Deficiencies in the reporting of implementation strategies and intervention descriptions made it challenging to identify all behaviour change content. It is possible that we may have missed some relevant intervention content during coding. While we developed coding rules to help prevent under or over-coding of BCTs, it is possible there were more behaviour change techniques associated with pediatric discharge communication interventions that we were unable to identify.

\section{Conclusions}

There is limited research identifying the active components of pediatric ED discharge communication interventions. The COM-B model and BCTTV1 provided a useful to analyse the barriers, enablers and common mechanisms used in these interventions. With only a fraction of the available BCTs used in the included studies, future research is needed to explore the utility of other BCTs to improve the effectiveness of discharge communication interventions. Further, the BCW presents an opportunity to prospectively design effective discharge communication interventions that incorporate prioritized BCTs using a systematic, theoretical approach. At a minimum, it is critical that intervention descriptions be standardized to ensure consistency in reporting, the ability to discern and evaluate successful intervention components, and to improve replicability moving forward.

\section{Abbreviations}


Behaviour Change Technique

BCTTv1

Behaviour Change Technique Taxonomy version 1

COM-B

Capability, Opportunity, Motivation- Behaviour

ED

Emergency Department

ENTREQ

Enhancing Transparency in Reporting the Synthesis of Qualitative Research

EPOC

Effective Practice and Organization of Care

MDIS

Metered Dose Inhaler with Spacer

NAEPP

National Asthma Education and Prevention Program

PCP

Primary Care Provider

RCP

Respiratory Care Practitioners

TDF

Theoretical Domains Framework

TIDiER

Template for Intervention Description and Replication

\section{Declarations}

Ethics approval and consent to participate

Not applicable.

Consent for publication

Not applicable.

Availability of data and material

Not applicable.

Competing interests

The authors declare that they have no competing interests.

Funding 
This work was not funded.

\section{Authors' contributions}

JAC conceived of the research question and method for this project. All authors participated in coding the $B C T s$, and JAC and AJG conducted coding of the barriers and enablers. AB and AJG prepared the first draft of the manuscript with input from CC, JE and JAC. All authors have made substantive contributions to revising the manuscript and have approved the final version.

\section{Acknowledgements}

None.

\section{References}

1. Craig P, Dieppe P, Macintyre S, Michie S, Nazareth I, Petticrew M. Developing and evaluating complex interventions: the new Medical Research Council guidance. BMJ. 2008;337:a1655.

2. Michie S, Fixsen D, Grimshaw JM, Eccles MP. Specifying and reporting complex behaviour change interventions: the need for a scientific method. Implement Sci IS. 2009;4:40.

3. Cochrane Effective Practice and Organisation of Care. EPOC Taxonomy | Cochrane Effective Practice and Organisation of Care. 2015. https://epoc.cochrane.org/epoc-taxonomy. Accessed 14 Nov 2019.

4. Hoffmann TC, Glasziou PP, Boutron I, Milne R, Perera R, Moher D, et al. Better reporting of interventions: template for intervention description and replication (TIDieR) checklist and guide. BMJ. 2014;348:g1687.

5. Lokker C, McKibbon KA, Colquhoun H, Hempel S. A scoping review of classification schemes of interventions to promote and integrate evidence into practice in healthcare. Implement Sci. 2015;10:27.

6. Cane J, O'Connor D, Michie S. Validation of the theoretical domains framework for use in behaviour change and implementation research. Implement Sci. 2012;7:37.

7. Michie S, Atkins L, West R. The Behaviour Change Wheel: A Guide to Designing Interventions. first edition. Great Britain: Silverback Publishing; 2014.

8. Alexander K, Brijnath B, Mazza D. Barriers and enablers to delivery of the Healthy Kids Check: An analysis informed by the Theoretical Domains Framework and COM-B model. Implement Sci. 2014;9.

9. McDonagh LK, Saunders JM, Cassell J, Curtis T, Bastaki H, Hartney T, et al. Application of the COM-B model to barriers and facilitators to chlamydia testing in general practice for young people and primary care practitioners: a systematic review. Implement Sci IS. 2018;13:130.

10. Michie S, Richardson M, Johnston M, Abraham C, Francis J, Hardeman W, et al. The behavior change technique taxonomy ( $\mathrm{v} 1$ ) of 93 hierarchically clustered techniques: building an international consensus for the reporting of behavior change interventions. Ann Behav Med Publ Soc Behav Med. 2013;46:81-95. 
11. Morrissey EC, Corbett TK, Walsh JC, Molloy GJ. Behavior Change Techniques in Apps for Medication Adherence: A Content Analysis. Am J Prev Med. 2016;50:e143-6.

12. Tate DF, Lytle L, Polzien K, Diamond M, Leonard KR, Jakicic JM, et al. Deconstructing Weight Management Interventions for Young Adults: Looking Inside the Black Box of the EARLY Consortium Trials. Obes Silver Spring Md. 2019;27:1085-98.

13. Currie S, Sinclair M, Murphy MH, Madden E, Dunwoody L, Liddle D. Reducing the Decline in Physical Activity during Pregnancy: A Systematic Review of Behaviour Change Interventions. PLOS ONE. 2013;8:e66385.

14. Yang C-H, Maher JP, Conroy DE. Implementation of Behavior Change Techniques in Mobile Applications for Physical Activity. Am J Prev Med. 2015;48:452-5.

15. McParland JL, Williams L, Gozdzielewska L, Young M, Smith F, MacDonald J, et al. What are the 'active ingredients' of interventions targeting the public's engagement with antimicrobial resistance and how might they work? Br J Health Psychol. 2018;23:804-19.

16. Presseau J, Ivers NM, Newham JJ, Knittle K, Danko KJ, Grimshaw JM. Using a behaviour change techniques taxonomy to identify active ingredients within trials of implementation interventions for diabetes care. Implement Sci. 2015;10:55.

17. Kebede MM, Liedtke TP, Möllers T, Pischke CR. Characterizing Active Ingredients of eHealth Interventions Targeting Persons With Poorly Controlled Type 2 Diabetes Mellitus Using the Behavior Change Techniques Taxonomy: Scoping Review. J Med Internet Res. 2017;19:e348.

18. Martin J, Chater A, Lorencatto F. Effective behaviour change techniques in the prevention and management of childhood obesity. Int J Obes 2005. 2013;37:1287-94.

19. Marcus $C$. Strategies for improving the quality of verbal patient and family education: a review of the literature and creation of the EDUCATE model. Health Psychol Behav Med. 2014;2:482-95.

20. Agency for Healthcare Research and Quality. Care Transitions from Hospital to Home: IDEAL Discharge Planning Implementation Handbook. Guide to Patient and Family Engagement.

21. Samuels-Kalow ME, Stack AM, Porter SC. Effective discharge communication in the emergency department. Ann Emerg Med. 2012;60:152-9.

22. Johns Hopkins University, Armstrong Institute for Patient Safety and Quality. Improving the emergency department discharge process: environmental scan report. (Prepared by Johns Hopkins University, Baltimore, MD, under Contract No. HHSA 2902010000271.) Rockville, MD: Agency for Healthcare Research and Quality; December 2014. AHRQ Publication No. 14(15)-0067-EF.

23. Curran JA, Gallant A, Zemek R, Newton AS, Jabbour M, Chorney J, et al. Discharge communication practices in pediatric emergency care: A systematic review and narrative synthesis. Syst Rev. 2019.

24. Craig P, Dieppe P, Macintyre S, Michie S, Nazareth I, Petticrew M, et al. Developing and evaluating complex interventions: the new Medical Research Council guidance. BMJ. 2008;337:a1655.

25. Curran JA, Murphy A, Newton M, Zemek R, Hartling L, Plint A, et al. Discharge instructions for caregivers in the context of pediatric emergency care: a narrative synthesis protocol. Syst Rev. 2014;3:26. 
26. Enhancing transparency in reporting the synthesis of qualitative research: ENTREQ. https://www.ncbi.nlm.nih.gov/pmc/articles/PMC3552766/. Accessed 15 Nov 2019.

27. NVivo. What is NVivo? I QSR International. http://www.qsrinternational.com/what-is-nvivo. Accessed 11 Sep 2017.

28. Dashboard- BCT Taxonomy Training. BCT Taxonomy Version 1 Online Training. http://www.bcttaxonomy.com/.

29. Wood CE, Richardson M, Johnston M, Abraham C, Francis J, Hardeman W, et al. Applying the behaviour change technique (BCT) taxonomy v1: a study of coder training. Transl Behav Med. 2015;5:134-48.

30. Delp C, Jones J. Communicating information to patients: the use of cartoon illustrations to improve comprehension of instructions. Acad Emerg Med Off J Soc Acad Emerg Med. 1996;3:264-70.

31. Bloch SA, Bloch AJ. Using video discharge instructions as an adjunct to standard written instructions improved caregivers' understanding of their child's emergency department visit, plan, and follow-up: a randomized controlled trial. Pediatr Emerg Care. 2013;29:699-704.

32. Ismail S, McIntosh M, Kalynych C, Joseph M, Wylie T, Butterfield R, et al. Impact of Video Discharge Instructions for Pediatric Fever and Closed Head Injury from the Emergency Department. J Emerg Med. 2016;50:e177-183.

33. Patel B, Kennebeck SS, Caviness AC, Macias CG. Use of a discharge facilitator improves recall of emergency department discharge instructions for acute gastroenteritis. Pediatr Emerg Care. 2009;25:558-64.

34. Brooks TM, Smith MM, Silvis RM, Lerer T, Mulvey $\mathrm{CH}$, Maitland R, et al. Symptom-Guided Emergency Department Discharge Instructions for Children With Concussion. Pediatr Emerg Care. 2017;33:55363.

35. Considine J, Brennan D. Effect of an evidence-based education programme on ED discharge advice for febrile children. J Clin Nurs. 2007;16:1687-94.

36. Smith SR, Jaffe DM, Highstein G, Fisher EB, Trinkaus KM, Strunk RC. Asthma coaching in the pediatric emergency department. Acad Emerg Med Off J Soc Acad Emerg Med. 2006;13:835-9.

37. Baker MD, Monroe KW, King WD, Sorrentino A, Glaeser PW. Effectiveness of fever education in a pediatric emergency department. Pediatr Emerg Care. 2009;25:565-8.

38. Chande VT, Wyss N, Exum V. Educational interventions to alter pediatric emergency department utilization patterns. Arch Pediatr Adolesc Med. 1996;150:525-8.

39. O'Neill-Murphy K, Liebman M, Barnsteiner JH. Fever education: does it reduce parent fever anxiety? Pediatr Emerg Care. 2001;17:47-51.

40. Jones SL, Jones PK, Katz J. A nursing intervention to increase compliance in otitis media patients. Appl Nurs Res ANR. 1989;2:68-73.

41. Porter SC, Forbes P, Feldman HA, Goldmann DA. Impact of patient-centered decision support on quality of asthma care in the emergency department. Pediatrics. 2006;117:e33-42. 
42. Ducharme FM, Zemek RL, Chalut D, McGillivray D, Noya FJD, Resendes S, et al. Written action plan in pediatric emergency room improves asthma prescribing, adherence, and control. Am J Respir Crit Care Med. 2011;183:195-203.

43. Sockrider MM, Abramson S, Brooks E, Caviness AC, Pilney S, Koerner C, et al. Delivering tailored asthma family education in a pediatric emergency department setting: a pilot study. Pediatrics. 2006;117 4 Pt 2:S135-144.

44. Isaacman DJ, Purvis K, Gyuro J, Anderson Y, Smith D. Standardized instructions: do they improve communication of discharge information from the emergency department? Pediatrics. 1992;89 $6 \mathrm{Pt}$ 2:1204-8.

45. Hussain-Rizvi A, Kunkov S, Crain EF. Does parental involvement in pediatric emergency department asthma treatment affect home management? J Asthma Off J Assoc Care Asthma. 2009;46:792-5.

46. To T, Wang C, Dell SD, Fleming-Carroll B, Parkin P, Scolnik D, et al. Can an evidence-based guideline reminder card improve asthma management in the emergency department? Respir Med. 2010;104:1263-70.

47. Rotheram-Borus MJ, Piacentini J, Cantwell C, Belin TR, Song J. The 18-month impact of an emergency room intervention for adolescent female suicide attempters. J Consult Clin Psychol. 2000;68:1081-93.

48. Cushman R, Down J, MacMillan N, Waclawik H. Helmet promotion in the emergency room following a bicycle injury: a randomized trial. Pediatrics. 1991;88:43-7.

49. Asarnow JR, Baraff LJ, Berk M, Grob CS, Devich-Navarro M, Suddath R, et al. An emergency department intervention for linking pediatric suicidal patients to follow-up mental health treatment. Psychiatr Serv Wash DC. 2011;62:1303-9.

50. Boychuk RB, Demesa CJ, Kiyabu KM, Yamamoto F, Yamamoto LG, Sanderson R, et al. Change in approach and delivery of medical care in children with asthma: results from a multicenter emergency department educational asthma management program. Pediatrics. 2006;117 4 Pt 2:S145-151.

51. Petersen DL, Murphy DE, Jaffe DM, Richardson MS, Fisher EB, Shannon W, et al. A tool to organize instructions at discharge after treatment of asthmatic children in an emergency department. J Asthma Off J Assoc Care Asthma. 1999;36:597-603.

52. Zorc JJ, Chew A, Allen JL, Shaw K. Beliefs and barriers to follow-up after an emergency department asthma visit: a randomized trial. Pediatrics. 2009;124:1135-42.

53. Yin HS, Dreyer BP, van Schaick L, Foltin GL, Dinglas C, Mendelsohn AL. Randomized controlled trial of a pictogram-based intervention to reduce liquid medication dosing errors and improve adherence among caregivers of young children. Arch Pediatr Adolesc Med. 2008;162:814-22.

54. Scarfi CA, Cunningham SJ, Wiznia A, Serebrisky D, Crain EF. Association between skin testing in the pediatric emergency department and adherence to follow-up in children with asthma. Ann Allergy Asthma Immunol Off Publ Am Coll Allergy Asthma Immunol. 2009;102:35-40.

55. Stevens N, Drendel AL, Weisman SJ. Video Education Intervention in the Emergency Department. 2012. 2012;:S76. 
56. Hart L, Nedadur R, Reardon J, Sirizzotti N, Poonai C, Speechley K, et al. 156: An Interactive Web-Based Module Versus Website and Standard of Care for Parental Fever Education: A Randomized Controlled Trial. Paediatr Child Health. 2015;20:e90-e90.

57. Wood EB, Harrison G, Trickey A, Friesen MA, Stinson S, Rovelli E, et al. Evidence-Based Practice: Video-Discharge Instructions in the Pediatric Emergency Department. J Emerg Nurs JEN Off Publ Emerg Dep Nurses Assoc. 2017;43:316-21.

58. Zorc JJ, Scarfone RJ, Li Y, Hong T, Harmelin M, Grunstein L, et al. Scheduled follow-up after a pediatric emergency department visit for asthma: a randomized trial. Pediatrics. 2003;111:495-502.

59. Komoroski EM, Graham CJ, Kirby RS. A comparison of interventions to improve clinic follow-up compliance after a pediatric emergency department visit. Pediatr Emerg Care. 1996;12:87-90.

60. Macy ML, Davis MM, Clark SJ, Stanley RM. Parental health literacy and asthma education delivery during a visit to a community-based pediatric emergency department: a pilot study. Pediatr Emerg Care. 2011;27:469-74.

61. Williams KW, Word C, Streck MR, Titus MO. Parental education on asthma severity in the emergency department and primary care follow-up rates. Clin Pediatr (Phila). 2013;52:612-9.

62. Gorelick MH, Meurer JR, Walsh-Kelly CM, Brousseau DC, Grabowski L, Cohn J, et al. Emergency department allies: a controlled trial of two emergency department-based follow-up interventions to improve asthma outcomes in children. Pediatrics. 2006;117 4 Pt 2:S127-134.

63. Kruesi MJ, Grossman J, Pennington JM, Woodward PJ, Duda D, Hirsch JG. Suicide and violence prevention: parent education in the emergency department. J Am Acad Child Adolesc Psychiatry. 1999;38:250-5.

64. LeMay S, Johnston C, Choinière M, Fortin C, Hubert I, Fréchette G, et al. Pain management interventions with parents in the emergency department: a randomized trial. J Adv Nurs. 2010;66:2442-9.

65. Stevens PK, Penprase B, Kepros JP, Dunneback J. Parental recognition of postconcussive symptoms in children. J Trauma Nurs Off J Soc Trauma Nurses. 2010;17:178-82; quiz 183-4.

66. Presseau J, Ivers NM, Newham JJ, Knittle K, Danko KJ, Grimshaw JM. Using a behaviour change techniques taxonomy to identify active ingredients within trials of implementation interventions for diabetes care. Implement Sci IS. 2015;10. doi:10.1186/s13012-015-0248-7.

67. Morrissey EC, Corbett TK, Walsh JC, Molloy GJ. Behavior Change Techniques in Apps for Medication Adherence: A Content Analysis. Am J Prev Med. 2016;50:e143-146.

68. Heron N, Kee F, Donnelly M, Cardwell C, Tully MA, Cupples ME. Behaviour change techniques in home-based cardiac rehabilitation: a systematic review. Br J Gen Pract. 2016;66:e747-57.

69. Direito A, Dale LP, Shields E, Dobson R, Whittaker R, Maddison R. Do physical activity and dietary smartphone applications incorporate evidence-based behaviour change techniques? BMC Public Health. 2014;14:646.

70. Dugdale S, Ward J, Hernen J, Elison S, Davies G, Donkor D. Using the Behavior Change Technique Taxonomy v1 to conceptualize the clinical content of Breaking Free Online: a computer-assisted 
therapy program for substance use disorders. Subst Abuse Treat Prev Policy. 2016;11:26.

71. Lorencatto F, West R, Stavri Z, Michie S. How well is intervention content described in published reports of smoking cessation interventions? Nicotine Tob Res Off J Soc Res Nicotine Tob. 2013;15:1273-82.

72. Lorencatto F, Smith L, Hamer M, Biddle S, Gardner B. Applying the BCT taxonomy to code sedentary behaviour reduction interventions: challenges and reflections. Eur Health Psychol. 2016;18 S:442.

73. Dr SM, Abraham C. Interventions to change health behaviours: evidence-based or evidence-inspired? Psychol Health. 2004;19:29-49.

74. Gollwitzer PM, Sheeran P. Implementation Intentions and Goal Achievement: A Meta-analysis of Effects and Processes. In: Advances in Experimental Social Psychology. Academic Press; 2006. p. 69-119. doi:10.1016/S0065-2601(06)38002-1.

75. Kwasnicka D, Presseau J, White M, Sniehotta FF. Does planning how to cope with anticipated barriers facilitate health-related behaviour change? A systematic review. Health Psychol Rev. 2013;7:129-45.

76. Dombrowski SU, Sniehotta FF, Avenell A, Johnston M, MacLennan G, Araújo-Soares V. Identifying active ingredients in complex behavioural interventions for obese adults with obesity-related comorbidities or additional risk factors for co-morbidities: a systematic review. Health Psychol Rev. 2012;6:7-32.

77. Villa-Roel C, Nikel T, Ospina M, Voaklander B, Campbell S, Rowe BH. Effectiveness of Educational Interventions to Increase Primary Care Follow-up for Adults Seen in the Emergency Department for Acute Asthma: A Systematic Review and Meta-analysis. Acad Emerg Med Off J Soc Acad Emerg Med. 2016;23:5-13.

78. Verheijden MW, Bakx JC, van Weel C, Koelen MA, van Staveren WA. Role of social support in lifestylefocused weight management interventions. Eur J Clin Nutr. 2005;59 Suppl 1:S179-186.

79. Kindler S. Social Support and its influence on online weight loss interventions: a systematic review. 2016. http://essay.utwente.nl/69222/. Accessed 14 Mar 2017.

80. Reblin M, Uchino BN. Social and emotional support and its implication for health. Curr Opin Psychiatry. 2008;21:201-5.

81. Samuels-Kalow M, Rhodes K, Uspal J, Reyes Smith A, Hardy E, Mollen C. Unmet Needs at the Time of Emergency Department Discharge. Acad Emerg Med. 2016;23:279-87.

82. Cheung A, Weir M, Mayhew A, Kozloff N, Brown K, Grimshaw J. Overview of systematic reviews of the effectiveness of reminders in improving healthcare professional behavior. Syst Rev. 2012;1:36.

83. Curran JA, Brehaut J, Patey AM, Osmond M, Stiell I, Grimshaw JM. Understanding the Canadian adult CT head rule trial: use of the theoretical domains framework for process evaluation. Implement Sci. 2013;8:25.

84. Michie S, Thomas J, Johnston M, Aonghusa PM, Shawe-Taylor J, Kelly MP, et al. The Human Behaviour-Change Project: harnessing the power of artificial intelligence and machine learning for evidence synthesis and interpretation. Implement Sci. 2017;12:121. 
85. Ioannidis JPA, Greenland S, Hlatky MA, Khoury MJ, Macleod MR, Moher D, et al. Increasing value and reducing waste in research design, conduct, and analysis. Lancet Lond Engl. 2014;383:166-75.

86. Carroll C, Patterson M, Wood S, Booth A, Rick J, Balain S. A conceptual framework for implementation fidelity. Implement Sci. 2007;2:40.

\section{Tables}

Table 1. Intervention barriers and enablers with identified COM-B domains 


\begin{tabular}{|c|c|c|c|c|}
\hline & Theme & $\begin{array}{l}\text { Barrier } \\
\text { or } \\
\text { Enabler }\end{array}$ & Example(s) & $\begin{array}{l}\text { Identified } \\
\text { COM-B } \\
\text { domain(s) }\end{array}$ \\
\hline \multirow[t]{2}{*}{$\begin{array}{l}\text { Caregiver } \\
\text { level }\end{array}$} & $\begin{array}{l}\text { Difficulty } \\
\text { understanding } \\
\text { discharge } \\
\text { communication [30- } \\
36]\end{array}$ & Barrier & $\begin{array}{l}\text { "if caregivers encountered difficulty with using the instructions, he or she } \\
\text { was then unable to effectively manage his or her child's condition in terms } \\
\text { of restricting activity, seeking follow-up care, administering medications, } \\
\text { and so on [34]." } \\
\text { "patients may not even realize the deficits in their own knowledge and } \\
\text { therefore do not pursue further clarification of instructions [31]." }\end{array}$ & $\begin{array}{l}\text { Psychological } \\
\text { capability }\end{array}$ \\
\hline & $\begin{array}{l}\text { Caregiver } \\
\text { stress/anxiety [35- } \\
40]\end{array}$ & Barrier & $\begin{array}{l}\text { "Often, these parents are quite anxious upon arrival to the busy ED } \\
\text { setting, where they have been dealing with the ill effects of fever and an } \\
\text { uncomfortable child for the past several hours at home [39]." } \\
\text { "parents are not receptive to advice when stressed or distracted [36]" }\end{array}$ & $\begin{array}{l}\text { Psychological } \\
\text { capability }\end{array}$ \\
\hline \multirow[t]{4}{*}{$\begin{array}{l}\text { Health care } \\
\text { provider } \\
\text { level }\end{array}$} & $\begin{array}{l}\text { Rapport between } \\
\text { health care } \\
\text { providers and } \\
\text { caregivers [30, 32, } \\
38,40,41]\end{array}$ & $\begin{array}{l}\text { Barrier } \\
\text { and } \\
\text { enabler }\end{array}$ & $\begin{array}{l}\text { "It is possible that the families enrolled in our study did not have a strong, } \\
\text { trusting relationship with their PCP and were uncomfortable calling him } \\
\text { or her with questions rather than returning to the PED [38]." } \\
\text { "Because many children receive episodic health care in ED settings, the } \\
\text { effectiveness of doctor-parent communication in this setting is of great } \\
\text { concern [30]." }\end{array}$ & $\begin{array}{l}\text { Psychological } \\
\text { capability }\end{array}$ \\
\hline & $\begin{array}{l}\text { Poor uptake of } \\
\text { intervention by } \\
\text { health care } \\
\text { provider [41-43] }\end{array}$ & Barrier & $\begin{array}{l}\text { "...a minority of plans that were generated by the kiosk were acted on by } \\
\text { providers. A mismatch between an activated patient and a less-than- } \\
\text { proactive provider may have widened a gap in partnership that the kiosk } \\
\text { was meant to narrow [41]." }\end{array}$ & $\begin{array}{l}\text { Social } \\
\text { opportunity }\end{array}$ \\
\hline & $\begin{array}{l}\text { Providing relevant } \\
\text { discharge } \\
\text { information early or } \\
\text { throughout the ED } \\
\text { visit }[35,44-46]\end{array}$ & Enabler & $\begin{array}{l}\text { "Anecdotal feedback from nursing staff was that many parents read the } \\
\text { material while waiting for medical assessment and once admitted to a } \\
\text { cubicle area, the majority of parents asked questions or sought } \\
\text { clarification of information contained in the handout [35]." }\end{array}$ & $\begin{array}{l}\text { Psychological } \\
\text { capabilities }\end{array}$ \\
\hline & $\begin{array}{l}\text { Training of } \\
\text { healthcare } \\
\text { providers }[35,47]\end{array}$ & Enabler & $\begin{array}{l}\text { "increasing staff training and skills to cope with suicidal youth, the ER } \\
\text { experience assisted in setting accurate, positive expectations for the } \\
\text { family's outpatient therapeutic experience [47]." }\end{array}$ & $\begin{array}{l}\text { Psychological } \\
\text { capability }\end{array}$ \\
\hline \multirow[t]{4}{*}{$\begin{array}{l}\text { Intervention } \\
\quad \text { level }\end{array}$} & $\begin{array}{l}\text { Intervention } \\
\text { complexity }[34,41 \text {, } \\
48,49]\end{array}$ & Barrier & $\begin{array}{l}\text { "Our intervention did not provide resources for time or additional } \\
\text { personnel to support the improvement effort [41]." }\end{array}$ & $\begin{array}{l}\text { Physical } \\
\text { opportunity }\end{array}$ \\
\hline & $\begin{array}{l}\text { Tailoring } \\
\text { interventions to } \\
\text { patient needs [33, } \\
42,43,50-52]\end{array}$ & Enabler & $\begin{array}{l}\text { "provided caregivers with detailed instructions to help them care for their } \\
\text { child with asthma and improve the child's symptoms [50]." }\end{array}$ & $\begin{array}{l}\text { Social } \\
\text { opportunity } \\
\text { and } \\
\text { psychological } \\
\text { capability }\end{array}$ \\
\hline & $\begin{array}{l}\text { Reinforcement of } \\
\text { discharge } \\
\text { communication }[32 \text {, } \\
39,42,44]\end{array}$ & Enabler & $\begin{array}{l}\text { "... providing educational materials in different formats (i.e., verbal, } \\
\text { written, and visual) offers an increased likelihood for comprehension } \\
\text { levels collectively [32]." }\end{array}$ & $\begin{array}{l}\text { Physical } \\
\text { opportunity }\end{array}$ \\
\hline & $\begin{array}{l}\text { Simple, low cost } \\
\text { interventions }[40 \text {, } \\
53,54]\end{array}$ & Enabler & $\begin{array}{l}\text { "The low resource requirements for this intervention...support its } \\
\text { potential utility in clinical practice [53]." }\end{array}$ & $\begin{array}{l}\text { Physical } \\
\text { opportunity }\end{array}$ \\
\hline
\end{tabular}




\begin{tabular}{|c|c|c|c|c|}
\hline & $\begin{array}{l}\text { Discharge } \\
\text { information } \\
\text { available in a } \\
\text { variety of } \\
\text { formats [30, 31, 39, } \\
41,45,50,51,53- \\
57]\end{array}$ & Enabler & $\begin{array}{l}\text { "Video discharge instructions have the potential to substantially mitigate } \\
\text { factors such as illiteracy, limited physician time, and variability in } \\
\text { communication skills among health care professionals, which may affect } \\
\text { comprehension, without adding a lot of extra time to the patient's total ED } \\
\text { visit. [31]." }\end{array}$ & $\begin{array}{l}\text { Psychological } \\
\text { capability }\end{array}$ \\
\hline \multirow[t]{3}{*}{$\begin{array}{l}\text { Health care } \\
\text { system } \\
\text { level }\end{array}$} & $\begin{array}{l}\text { Appropriate use of } \\
\text { primary care }[36, \\
40,51,58]\end{array}$ & Barrier & $\begin{array}{l}\text { “...infrequent use of primary care may greatly affect morbidity among } \\
\text { economically disadvantaged children. [51].” }\end{array}$ & $\begin{array}{l}\text { Physical } \\
\text { opportunity } \\
\text { and social } \\
\text { opportunity }\end{array}$ \\
\hline & $\begin{array}{l}\text { ED context }[32,33 \\
35,39,41,49,50]\end{array}$ & Barrier & $\begin{array}{l}\text { "In addition, the bustling ED setting adds additional stress to the parents } \\
\text { because of the long wait and the loud and chaotic nature of the } \\
\text { environment [39]." }\end{array}$ & $\begin{array}{l}\text { Physical } \\
\text { opportunity }\end{array}$ \\
\hline & $\begin{array}{l}\text { Knowledge } \\
\text { exchange between } \\
\text { ED care and } \\
\text { primary care } \\
\text { provider (PCP) }[49, \\
50,58,59]\end{array}$ & Enabler & $\begin{array}{l}\text { "In an effort to enhance communication between the patient and his or } \\
\text { her PCP, ED visit information was faxed to the PCP. Such communication } \\
\text { is important in linking care between health care providers, because } \\
\text { asthma is a chronic disease that requires continuous care, monitoring, and } \\
\text { reinforcement of education [50]." }\end{array}$ & $\begin{array}{l}\text { Reflective } \\
\text { motivation } \\
\text { and physical } \\
\text { opportunity }\end{array}$ \\
\hline
\end{tabular}

$\mathrm{COM}-\mathrm{B}=$ Capability, opportunity, motivation- behaviour model $\mathrm{ED}=$ emergency department; $\mathrm{PCP}=$ primary care provider; $\mathrm{PED}=$ pediatrics emergency department

Table 2. Summary of included studies and identified BCTs. 


\begin{tabular}{|c|c|c|c|c|}
\hline $\begin{array}{l}\text { Author and } \\
\text { Year }\end{array}$ & $\begin{array}{l}\text { Illness } \\
\text { Presentation(s) }\end{array}$ & Study Objective(s) & $\begin{array}{c}\text { BCTs Identified } \\
\text { Targeted at } \\
\text { Patients/Caregivers }\end{array}$ & $\begin{array}{l}\text { BCTs Identified } \\
\text { Targeted at Health } \\
\text { Care Providers }\end{array}$ \\
\hline $\begin{array}{l}\text { Asarnow et } \\
\text { al., } \\
\text { 2011[49] }\end{array}$ & Mental health & $\begin{array}{l}\text { To evaluate a suicide prevention intervention to improve } \\
\text { use of outpatient care and decrease suicide attempts }\end{array}$ & $\begin{array}{l}\text { 1.4- action planning } \\
\text { 3.1- social support } \\
\text { (unspecified) } \\
\text { 3.3- social support } \\
\text { (emotional) } \\
\text { 7.1- prompts/cues } \\
\text { 12.1- restructuring the } \\
\text { physical environment } \\
\text { 12.5- adding objects to } \\
\text { the environment } \\
\text { 13.2- } \\
\text { framing/reframing }\end{array}$ & $\begin{array}{l}\text { 4.1- instruction on } \\
\text { how to perform the } \\
\text { behaviour } \\
\text { 8.1- behaviour } \\
\text { practice/ rehearsal }\end{array}$ \\
\hline $\begin{array}{c}\text { Baker et al., } \\
2009 \text { [37] }\end{array}$ & Fever & $\begin{array}{l}\text { To determine if an educational video of home } \\
\text { management of fevers could reduce return ED visits }\end{array}$ & $\begin{array}{l}\text { 4.1- instruction on how } \\
\text { to perform the } \\
\text { behaviour }\end{array}$ & \\
\hline $\begin{array}{l}\text { Bloch \& } \\
\text { Bloch, } \\
2013[31]\end{array}$ & $\begin{array}{l}\text { Asthma, fever, } \\
\text { vomiting, or } \\
\text { diarrhea }\end{array}$ & $\begin{array}{l}\text { To determine if a video providing discharge information } \\
\text { would improve home management of a child's illness }\end{array}$ & $\begin{array}{l}\text { 4.1- instruction on how } \\
\text { to perform the } \\
\text { behaviour }\end{array}$ & \\
\hline $\begin{array}{l}\text { Boychuk et } \\
\text { al., } \\
2006 \text { [50] }\end{array}$ & Asthma & $\begin{array}{l}\text { To develop and implement an asthma education program } \\
\text { based on National Asthma Education and Prevention } \\
\text { Program (NAEPP) guidelines }\end{array}$ & $\begin{array}{l}\text { 1.4- action planning } \\
\text { 3.2- social support } \\
\text { (practical) } \\
\text { 4.1- instruction on how } \\
\text { to perform the } \\
\text { behaviour } \\
\text { 5.1-information about } \\
\text { health consequences } \\
\text { 6.1- demonstration of } \\
\text { the behaviour } \\
\text { 7.1-prompts/cues }\end{array}$ & $\begin{array}{l}\text { 4.1-instruction on } \\
\text { how to perform the } \\
\text { behaviour } \\
\text { 5.1-information } \\
\text { about health } \\
\text { consequences }\end{array}$ \\
\hline
\end{tabular}




\begin{tabular}{|c|c|c|c|c|}
\hline & & & 9.1-credible source & \\
\hline $\begin{array}{l}\text { Brooks et } \\
\quad \text { al., } \\
2017 \text { [34] }\end{array}$ & Concussion & $\begin{array}{l}\text { To determine the usability of symptom-guided discharge } \\
\text { instruction intervention }\end{array}$ & $\begin{array}{l}\text { 4.1- instruction on how } \\
\text { to perform the } \\
\text { behaviour }\end{array}$ & \\
\hline $\begin{array}{l}\text { Chande et } \\
\text { al., } \\
1996[38]\end{array}$ & Minor illnesses & $\begin{array}{l}\text { To determine if educating caregivers could reduce } \\
\text { unnecessary return ED visits }\end{array}$ & $\begin{array}{l}\text { 4.1- instruction on how } \\
\text { to perform the } \\
\text { behaviour }\end{array}$ & \\
\hline $\begin{array}{l}\text { Considine \& } \\
\text { Brennan, } \\
2007 \text { [35] }\end{array}$ & Fever & $\begin{array}{l}\text { To examine the effect of a staff educational intervention } \\
\text { on discharge advice provided to caregivers leaving the } \\
\text { ED }\end{array}$ & & $\begin{array}{l}\text { 5.1-information } \\
\text { about health } \\
\text { consequences }\end{array}$ \\
\hline $\begin{array}{l}\text { Cushman et } \\
\text { al., } \\
1991[48]\end{array}$ & Head injury & $\begin{array}{l}\text { To encourage the purchase of helmets following a visit to } \\
\text { the ED with a child with a bike injury }\end{array}$ & $\begin{array}{l}\text { 3.1- social support } \\
\text { (unspecified) } \\
\text { 3.2- social support } \\
\text { (practical) } \\
\text { 5.1- information about } \\
\text { health consequences } \\
\text { 9.1- credible source }\end{array}$ & 7.1- prompts/ cues \\
\hline $\begin{array}{l}\text { Delp and } \\
\text { Jones, } \\
1996[30]\end{array}$ & Lacerations & $\begin{array}{l}\text { To improvie caregiver comprehension with the use of } \\
\text { illustrated discharge information }\end{array}$ & $\begin{array}{l}\text { 4.1-instruction on how } \\
\text { to perform the } \\
\text { behaviour } \\
\text { 5.1-information about } \\
\text { health consequences }\end{array}$ & \\
\hline $\begin{array}{l}\text { Ducharme } \\
\text { et al., } \\
2011 \text { [42] }\end{array}$ & Asthma & $\begin{array}{l}\text { To determine if providing written discharge information } \\
\text { and a prescription improved compliance with asthma } \\
\text { discharge information }\end{array}$ & $\begin{array}{l}\text { 2.1- monitoring of } \\
\text { behaviours by others } \\
\text { without feedback } \\
\text { 4.1- instruction on how } \\
\text { to perform the } \\
\text { behaviour } \\
\text { 12.5- adding objects to } \\
\text { environment }\end{array}$ & 7.1- prompts/ cues \\
\hline $\begin{array}{c}\text { Gorelick et } \\
\text { al., } \\
2006 \text { [62] }\end{array}$ & Asthma & $\begin{array}{l}\text { To compare asthma interventions in the ED on return } \\
\text { visits }\end{array}$ & $\begin{array}{l}\text { 1.4- action planning } \\
\text { 3.2- social support } \\
\text { (practical) } \\
\text { 4.1- instruction on how } \\
\text { to perform the } \\
\text { behaviour }\end{array}$ & \\
\hline $\begin{array}{l}\text { Hart et al, } \\
2015[56]\end{array}$ & Fever & $\begin{array}{l}\text { To improve caregivers' knowledge of fever with an } \\
\text { interactive online education resource }\end{array}$ & $\begin{array}{l}\text { 5.1-information about } \\
\text { health consequences }\end{array}$ & \\
\hline
\end{tabular}




\begin{tabular}{|c|c|c|c|c|}
\hline $\begin{array}{l}\text { Hussain- } \\
\text { Rizvi et al., } \\
2009 \text { [45] }\end{array}$ & Asthma & $\begin{array}{l}\text { To improve caregiver compliance with asthma home } \\
\text { management by providing metered dose inhaler with } \\
\text { spacers } \\
\text { (MDIS) with physician supervision }\end{array}$ & $\begin{array}{l}\text { 8.1- behaviour } \\
\text { practice/rehearsal } \\
\text { 9.1- credible source }\end{array}$ & \\
\hline $\begin{array}{l}\text { Isaacman et } \\
\text { al., } \\
1992[44]\end{array}$ & Otitis media & $\begin{array}{l}\text { To determine if offering verbal or verbal and written } \\
\text { discharge information would improve information recall }\end{array}$ & & $\begin{array}{l}\text { 4.1- instruction on } \\
\text { how to perform the } \\
\text { behaviour } \\
\text { 7.1- prompts/ cues }\end{array}$ \\
\hline $\begin{array}{c}\text { Ismail et al., } \\
2016 \text { [32] }\end{array}$ & $\begin{array}{l}\text { Fever and closed } \\
\text { head injury }\end{array}$ & $\begin{array}{l}\text { To improve caregiver recall and comprehension by } \\
\text { providing video discharge information }\end{array}$ & $\begin{array}{l}\text { 4.1- instruction on how } \\
\text { to perform the } \\
\text { behaviour }\end{array}$ & \\
\hline $\begin{array}{c}\text { Jones et al., } \\
1989 \text { [40] }\end{array}$ & Otitis media & $\begin{array}{l}\text { To use nursing interventions to increase compliance with } \\
\text { follow up care }\end{array}$ & $\begin{array}{l}\text { 3.2- social support } \\
\text { (practical) }\end{array}$ & \\
\hline $\begin{array}{l}\text { Komoroski } \\
\text { et al., } \\
1996 \text { [59] }\end{array}$ & $\begin{array}{l}\text { Acute infections } \\
\text { or non-urgent ED } \\
\text { presentation }\end{array}$ & $\begin{array}{l}\text { To determine the effectiveness of interventions aimed at } \\
\text { improving rates of follow up care }\end{array}$ & $\begin{array}{l}\text { 3.1- social support } \\
\text { (unspecified) } \\
\text { 3.2- social support } \\
\text { (practical) } \\
\text { 7.1- prompts/cues } \\
\text { 12.5- adding objects to } \\
\text { the environment }\end{array}$ & \\
\hline $\begin{array}{l}\text { Kruesi et } \\
\text { al., } \\
1999 \text { [63] }\end{array}$ & Mental health & $\begin{array}{l}\text { To examine if injury prevention education could reduce } \\
\text { access to lethal means }\end{array}$ & $\begin{array}{l}\text { 1.2- problem solving } \\
\text { 3.2-social support } \\
\text { (practical) } \\
\text { 5.1- information about } \\
\text { health consequences } \\
\text { 12.1- restructuring the } \\
\text { physical environment }\end{array}$ & \\
\hline $\begin{array}{l}\text { Le May et } \\
\quad \text { al., } \\
2010[64]\end{array}$ & Various injuries & $\begin{array}{l}\text { To test an education intervention about pediatric pain } 24 \\
\text { hours following ED discharge }\end{array}$ & $\begin{array}{l}\text { 5.1- information about } \\
\text { health consequences }\end{array}$ & \\
\hline $\begin{array}{c}\text { O’Neill- } \\
\text { Murphy et } \\
\text { al., } \\
2001 \text { [39] }\end{array}$ & Fever & $\begin{array}{l}\text { To test a fever education intervention to reduce } \\
\text { caregiver anxiety and improve home management of } \\
\text { fevers }\end{array}$ & $\begin{array}{l}\text { 5.1- information about } \\
\text { health consequences } \\
\text { 6.1- demonstration of } \\
\text { the behaviour }\end{array}$ & \\
\hline $\begin{array}{c}\text { Patel et al., } \\
2009 \text { [33] }\end{array}$ & Gastroenteritis & $\begin{array}{l}\text { To improve caregiver recall of verbal discharge } \\
\text { information with the use of a bilingual discharge } \\
\text { facilitator }\end{array}$ & $\begin{array}{l}\text { 3.1- social support } \\
\text { (unspecified) } \\
\text { 3.2- social support } \\
\text { (practical) }\end{array}$ & \\
\hline
\end{tabular}




\begin{tabular}{|c|c|c|c|c|}
\hline & & & $\begin{array}{l}\text { 4.1- instruction on how } \\
\text { to perform the } \\
\text { behaviour } \\
\text { 5.1- information about } \\
\text { health consequences }\end{array}$ & \\
\hline $\begin{array}{l}\text { Petersen et } \\
\text { al., } \\
1999[51]\end{array}$ & Asthma & $\begin{array}{l}\text { To determine if creating an asthma education tool } \\
\text { improved rates of follow up care }\end{array}$ & & $\begin{array}{l}\text { 4.1- instruction on } \\
\text { how to perform the } \\
\text { behaviour }\end{array}$ \\
\hline $\begin{array}{l}\text { Porter et } \\
\quad \text { al., } \\
2006[41]\end{array}$ & Asthma & $\begin{array}{l}\text { To determine the effectiveness of an asthma information } \\
\text { kiosk on caregiver satisfaction, and clinician use of the } \\
\text { kiosk information }\end{array}$ & & 7.1- prompts/ cues \\
\hline $\begin{array}{l}\text { Rotheram- } \\
\text { Borus et al., } \\
2000 \text { [47] }\end{array}$ & Mental health & $\begin{array}{l}\text { To decrease suicidal behaviours with outpatient therapy } \\
\text { compliance }\end{array}$ & $\begin{array}{l}\text { 1.2- problem solving } \\
\text { 1.4- action planning } \\
\text { 3.2- social support } \\
\text { (practical) } \\
\text { 3.3- social support } \\
\text { (emotional) } \\
\text { 4.1- instruction on how } \\
\text { to perform the } \\
\text { behaviour } \\
\text { 5.1- information about } \\
\text { health consequences } \\
\text { 6.1- demonstration of } \\
\text { the behaviour } \\
\text { 8.1- behaviour } \\
\text { practice/rehearsal } \\
\text { identity }\end{array}$ & \\
\hline $\begin{array}{l}\text { Scarfi et } \\
\text { al., } \\
2009[54]\end{array}$ & Asthma & $\begin{array}{l}\text { To determine if allergen skin testing for asthma during an } \\
\text { ED visit would improve follow up rates at an asthma clinic }\end{array}$ & $\begin{array}{l}\text { 2.6- biofeedback } \\
\text { 10.8- incentive } \\
\text { (outcome) }\end{array}$ & \\
\hline $\begin{array}{l}\text { Smith et al., } \\
2006[36]\end{array}$ & Asthma & $\begin{array}{l}\text { To determine if providing asthma coaching and incentives } \\
\text { would improve rates of follow up care with a primary } \\
\text { care provider }\end{array}$ & $\begin{array}{l}\text { 1.2- problem solving } \\
\text { 3.1- social support } \\
\text { (unspecified) }\end{array}$ & \\
\hline
\end{tabular}




\begin{tabular}{|c|c|c|c|c|}
\hline & & & $\begin{array}{l}\text { 10.2- material reward } \\
\text { (behaviour) }\end{array}$ & \\
\hline $\begin{array}{l}\text { Sockrider } \\
\text { et al., } \\
2006[43]\end{array}$ & Asthma & $\begin{array}{l}\text { To test a tailored asthma management intervention to } \\
\text { improve caregiver confidence and reduce return ED visits }\end{array}$ & $\begin{array}{l}\text { 1. goal setting } \\
\text { 3.2- social } \\
\text { support(practical) } \\
\text { 4.1- instruction on how } \\
\text { to perform the } \\
\text { behaviour } \\
\text { 7.1- prompts/cues } \\
\text { 9.1- credible source }\end{array}$ & \\
\hline $\begin{array}{l}\text { Stevens et } \\
\quad \text { al., } \\
2012 \text { [65] }\end{array}$ & Pediatric pain & $\begin{array}{l}\text { To determine the effect of a pain management video on } \\
\text { caregivers' knowledge and pain medication use following } \\
\text { ED discharge }\end{array}$ & $\begin{array}{l}\text { 4.1- instruction on how } \\
\text { to perform the } \\
\text { behaviour } \\
\text { 5.1- information about } \\
\text { health consequences }\end{array}$ & \\
\hline $\begin{array}{l}\text { To et al., } \\
2010[46]\end{array}$ & Asthma & $\begin{array}{l}\text { To determine if an asthma information card would } \\
\text { improve asthma management in the ED }\end{array}$ & 7.1-prompts/cues & \\
\hline $\begin{array}{c}\text { Wood et al., } \\
2017 \text { [57] }\end{array}$ & Various Illnesses & $\begin{array}{l}\text { To determine the impact of video discharge instructions } \\
\text { compared to written/verbal instructions on caregiver } \\
\text { knowledge }\end{array}$ & $\begin{array}{l}\text { 5.1-information about } \\
\text { health consequences }\end{array}$ & \\
\hline $\begin{array}{l}\text { Yin et al., } \\
2008[53]\end{array}$ & Various illnesses & $\begin{array}{l}\text { To determine if the use of illustrated health literacy } \\
\text { interventions helped decrease liquid medication dosing } \\
\text { errors }\end{array}$ & $\begin{array}{l}\text { 4.1- instruction on how } \\
\text { to perform the } \\
\text { behaviour } \\
\text { 6.1- demonstration of } \\
\text { the behaviour } \\
\text { 8.1- behaviour } \\
\text { practice/rehearsal } \\
\text { 12.5- adding objects to } \\
\text { environment }\end{array}$ & \\
\hline $\begin{array}{c}\text { Zorc et al., } \\
2003[58]\end{array}$ & Asthma & $\begin{array}{l}\text { To determine the effectiveness of scheduling follow-up } \\
\text { appointments to help manage asthma cases }\end{array}$ & $\begin{array}{l}\text { 3.2- social support } \\
\text { (practical) }\end{array}$ & \\
\hline $\begin{array}{c}\text { Zorc et al., } \\
2009[52]\end{array}$ & Asthma & $\begin{array}{l}\text { To develop and test a three part asthma intervention to } \\
\text { improve rates of follow up care }\end{array}$ & $\begin{array}{l}\text { 7.1- prompts/cues } \\
\text { 9.1- credible source }\end{array}$ & \\
\hline
\end{tabular}


$\mathrm{BCT}=$ behavior change technique, $\mathrm{ED}=$ emergency department, $\mathrm{MDIS}=$ metered dose inhaler with spacer, NAEPP= National Asthma Education and Prevention Program

\section{Figures}

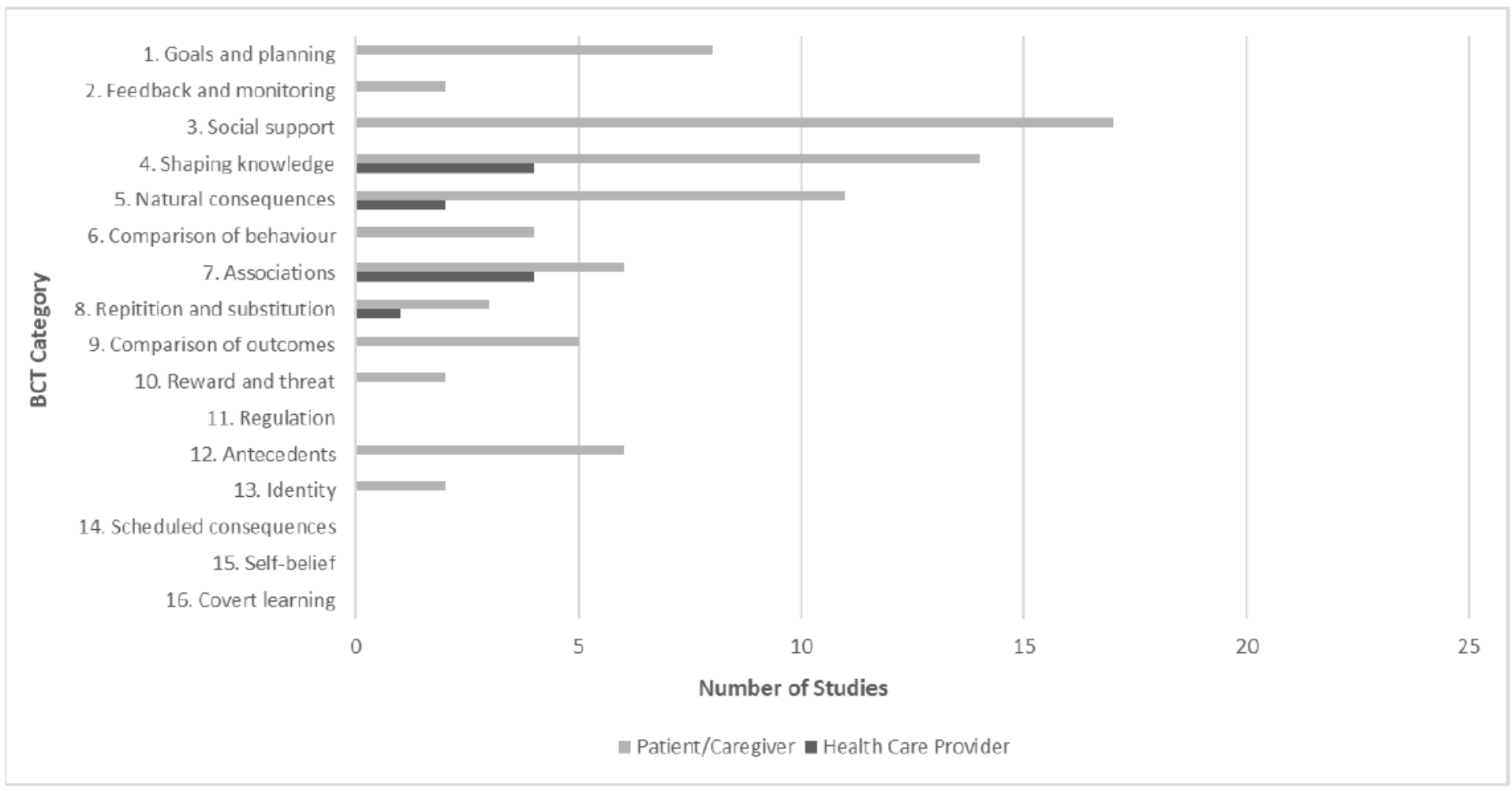

Figure 2

BCT category coding frequency by intervention target

\section{Supplementary Files}

This is a list of supplementary files associated with this preprint. Click to download.

- AdditionalFile1.ENTERQchecklist.docx

- AdditionalFile1.ENTERQchecklist.docx 